\title{
Crystal Structure and Solution Structural Dynamic Feature of 1,8-Dibenzoyl-2,7-Dimethoxynaphthalene
}

\author{
Akiko Okamoto, Shoji Watanabe, Kosuke Nakaema, Noriyuki Yonezawa \\ Department of Organic and Polymer Materials Chemistry, Tokyo University of Agriculture and Technology, Tokyo, Japan \\ Email: aokamoto@cc.tuat.ac.jp
}

Received October 26, 2012; revised November 30, 2012; accepted December 8, 2012

\begin{abstract}
The crystal structure and the dynamic feature of molecular structure in solution for 1,8-dibenzoyl-2,7-dimethoxynaphthalene are revealed by X-ray crystallographic analysis and VT-NMR measurements. In crystal, the molecule of the title compound is located on a twofold rotation axis. The two benzoyl groups are situated in an opposite direction. The dihedral angle between the mean planes of the phenyl ring and the naphthalene ring system is $80.25(6)^{\circ}$. The benzene ring and carbonyl moiety in each benzoyl group are almost coplanar. The molecular packing is stabilized by weak $\mathrm{C}-\mathrm{H}$...O hydrogen bonds and a $\pi-\pi$ stacking interaction between the benzene rings [centroid-centroid and interplanar distances of 3.6383(10) and $3.294 \AA$, respectively]. In solution, the temperature-dependent rotation behavior of the $\mathrm{C}-\mathrm{C}$ bond between the benzene ring and the ketonic carbonyl group has been observed by ${ }^{1} \mathrm{H}$ VT-NMR measurements. Furthermore, comparison of the $\mathrm{C}-\mathrm{C}$ bond rotation behavior between the benzene ring and the carbonyl group with 1-benzoyl-2,7-dimethoxynaphthalene has clarified that the $\mathrm{C}-\mathrm{C}$ bond between the ketonic carbonyl group and the naphthalene ring rotates slower than the 1,8-dibenzoylated homologue.
\end{abstract}

Keywords: Non-Coplanarly Accumulated Aromatic Rings Molecules; Crystal Structural Features; Bond Rotation Behavior in Solution; X-Ray Crystallography; VT-NMR Spectroscopy

\section{Introduction}

Non-coplanarly accumulated aromatic rings molecules, such as binaphthyl and biphenyl compounds, have attracted significant attention because of their characteristic properties, unique shapes, and various applications [1-7]. Peri-substituted naphthalenes have also received much attention as unique structured aromatic core compounds for variety of the functional materials [8-12]. Therefore, the structural analyses have been actively performed [13-15]. Recently, the authors' group has revealed that diaroylation at 1,8-positions of 2,7-dimethoxynaphthalene smoothly proceeds $[16,17]$. According to $\mathrm{X}$-ray crystal structural study, the obtained 1,8-diaroylnaphthalene has unique non-coplanar alignment of aromatic rings [18]. The curious reversible aroylation behavior of the naphthalene derivative [16] and chemospecific and regioselective ethereal alkyl-oxygen bond cleavage reaction of aroylated naphthalenes [19] can be explained on the basis of the structural features of the aroylated naphthalenes. Under these circumstances, the authors have undertaken the structural studies of the aroylnaphthalne compounds [20-26] with investigation of the formation and the related reaction behaviors.

In this article, the crystallographical structural charac- teristics and the dynamic feature in solution structure of a 1,8-diaroylated naphthalene derivative having two methoxy groups at the 2,7-positions are described as the most simple homologue of monoaroylated derivative.

\section{Experimental}

All reagents were of commercial quality and were used as received. Solvents were dried and purified using standard techniques. Pentoxide-methanesulfonic acid $\left(\mathrm{P}_{2} \mathrm{O}_{5^{-}}\right.$ $\mathrm{MsOH}$ ) was prepared according to literature [27].

\subsection{Measurements}

${ }^{1} \mathrm{H}$ NMR spectra were recorded on a JEOL JNM-AL300 spectrometer $(300 \mathrm{MHz})$ and a JEOL ECX400 spectrometer $(400 \mathrm{MHz})$. Chemical shifts are expressed in ppm relative to internal standard of $\mathrm{Me}_{4} \mathrm{Si}(\delta 0.00) .{ }^{13} \mathrm{C}$ NMR spectra were recorded on a JEOL JNM-AL300 spectrometer $(75 \mathrm{MHz})$. Chemical shifts are expressed in ppm relative to internal standard of $\mathrm{CDCl}_{3}(\delta 77.0)$. IR spectra were recorded on a JASCO FT/IR-4100 spectrometer. High-resolution FAB mass spectra were recorded on a JEOL MStation (MS700) ion trap mass spectrometer in positive ion mode. 


\subsection{Synthetic Procedure of the Title Compound}

The title compound was synthesized via direct condensation mediated by $\mathrm{P}_{2} \mathrm{O}_{5}$-MsOH of 2,7-dimethoxynaphthalene with benzoic acid (Scheme 1). To a mixture of 2,7-dimethoxynaphthalene $(0.200 \mathrm{mmol}, 37.6 \mathrm{mg})$ and benzoic acid $(0.440 \mathrm{mmol}, 174 \mathrm{mg}), \mathrm{P}_{2} \mathrm{O}_{5}-\mathrm{MsOH}(0.88$ $\mathrm{mL}$ ) was added by portions at $\mathrm{rt}$. After the reaction mixture was stirred at $60^{\circ} \mathrm{C}$ for $3 \mathrm{~h}$, it was poured into iced water $(20 \mathrm{~mL})$ and the mixture was extracted with $\mathrm{CHCl}_{3}$ $(15 \mathrm{~mL} \times 3)$. The combined extracts were washed with 2 $\mathrm{M} \mathrm{NaOH}$ aq and followed by sat $\mathrm{NaCl}$ aq. The organic layers thus obtained were dried over anhydrous sodium sulfate. The solvent was removed under reduced pressure to give powdery product. Isolation of the title compound was carried out by column chromatography [hexane: AcOEt $=2: 1]$ (1,8-diaroylnaphthalene 63\%; 3-monoaroylnaphthalene $19 \%$; 1-monoaroylnaphthalene 3\%). Colorless single crystals suitable for X-ray diffraction were obtained by recrystallization from ethanol.

1,8-benzoyl-2,7-dimethoxynaphthalene: Colorless needle $(\mathrm{EtOH}) ;$ m.p. $=530 \mathrm{~K}$; IR $(\mathrm{KBr}): 1665,1626 \mathrm{~cm}^{-1}$; ${ }^{1} \mathrm{H} \mathrm{NMR} \quad\left(400 \mathrm{MHz}, \mathrm{CDCl}_{3}\right): 3.68(6 \mathrm{H}, \mathrm{s}), 7.21(2 \mathrm{H}, \mathrm{d}$, $J=9.2 \mathrm{~Hz}), 7.34$ (4H, dd, $J=7.6,7.6 \mathrm{~Hz}), 7.49$ (2H, t, $J$ $=7.4 \mathrm{~Hz}), 7.70(4 \mathrm{H}, \mathrm{d}, J=7.4 \mathrm{~Hz}), 7.95(2 \mathrm{H}, \mathrm{d}, J=9.2$ $\mathrm{Hz})$ ppm; ${ }^{13} \mathrm{C} \mathrm{NMR} \quad\left(75 \mathrm{MHz}, \mathrm{CDCl}_{3}\right): 56.40,111.24$, $121.47,125.55,127.95,129.09,129.84,132.03$, 132.64, 138.61, 156.28, $196.875 \mathrm{ppm}$. The above melting point and spectral data are compatible with the literature [28].

1-benzoyl-2,7-dimethoxynaphthalene:Colorless plate (Hexane + methylenechloride); m.p. $=358.5$ - $362 \mathrm{~K}$; IR (KBr): $1663,1627 \mathrm{~cm}^{-1}$; ${ }^{1} \mathrm{H}$ NMR $\delta\left(400 \mathrm{MHz}, \mathrm{CDCl}_{3}\right)$ : $3.71(3 \mathrm{H}, \mathrm{s}), 3.79(3 \mathrm{H}, \mathrm{s}), 6.80(1 \mathrm{H}, \mathrm{d}, J=2.8 \mathrm{~Hz}), 7.01$ $(1 \mathrm{H}, \mathrm{dd}, J=9.2,2.8 \mathrm{~Hz}), 7.17(1 \mathrm{H}, \mathrm{d}, J=9.2 \mathrm{~Hz}), 7.43$ $(2 \mathrm{H}, \mathrm{t}, J=8.0 \mathrm{~Hz}), 7.57(1 \mathrm{H}, \mathrm{t}, J=8.2 \mathrm{~Hz}), 7.72(1 \mathrm{H}, \mathrm{d}$, $J=8.0 \mathrm{~Hz}), 7.84-7.89(3 \mathrm{H}, \mathrm{m}) \mathrm{ppm} ;{ }^{13} \mathrm{C} \mathrm{NMR} \quad(75$ $\left.\mathrm{MHz}, \mathrm{CDCl}_{3}\right)$ : 55.09, 56.24, 102.02, 110.17, 117.01, $121.67,124.29,128.48,129.44,129.62,130.96,132.98$, 133.31, 137.98, 154.93, 158.77, 198.07 ppm; HRMS (FAB; $m$-nitrobenzyl alcohol $[m-\mathrm{NBA}]) \mathrm{m} / \mathrm{z}$ : $[\mathrm{M}+\mathrm{H}]^{+}$; Calcd for $\mathrm{C}_{19} \mathrm{H}_{17} \mathrm{O}_{3}$, 293.3365; found, 293.1185.

\subsection{X-Ray Crystallography}

For the crystal structure determination, the single-crystal

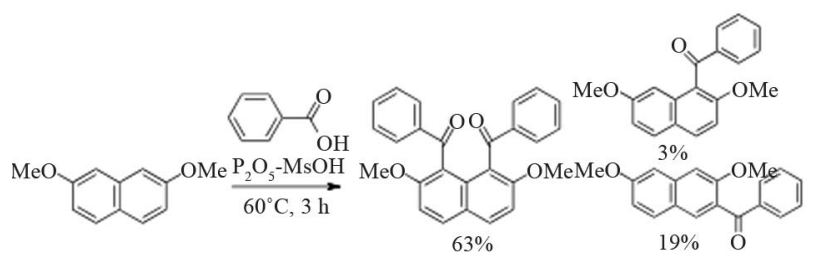

Scheme 1. Synthetic reaction of the title compound: $\mathbf{P}_{2} \mathbf{O}_{5^{-}}$ $\mathrm{MsOH}$ mediated direct condensation of 2,7-dimethoxynaphthalene with benzoic acid. of the compound $\mathrm{C}_{26} \mathrm{H}_{20} \mathrm{O}_{4}$ was used for data collection on a four-circle Rigaku R-AXIS RAPID diffractometer (equipped with a two-dimensional area IP detector). The graphite-mono-chromated $\mathrm{Cu} \mathrm{K} \alpha$ radiation $(\lambda=1.54187$ $\AA$ ) was used for data collection. The lattice parameters were determined by the least-squares methods on the basis of all reflections with $F^{2}>2 \sigma\left(F^{2}\right)$. The data collection and cell refinement were performed using $P R O C$ ESS-AUTO [29] software. The data reduction was performed using CrystalStructure [30]. The structures were solved by direct methods using SIR2004 [31] and refined by a full-matrix least-squares procedure using the program SHELXL97 [32]. All H atoms were found in a difference map and were subsequently refined as riding atoms, with the aromatic $\mathrm{C}-\mathrm{H}=0.95 \AA$ and methyl $\mathrm{C}-\mathrm{H}=$ $0.98 \AA$, and with $U_{\text {iso }}(\mathrm{H})=1.2 U_{\text {eq }}(\mathrm{C})$. Molecular structure of the compound showing the atomic numbering scheme is shown in Figure 1. The crystallography details for the structures determination of the compound are displayed presented in Table 1.

\subsection{Variable Temperature NMR}

Variable temperature ${ }^{1} \mathrm{H}$ NMR spectra were recorded on an FT-NMR operating at $400 \mathrm{MHz}$. Chemical shift values were reported in parts per million (ppm) relative to $\left(\mathrm{CH}_{3}\right)_{4} \mathrm{Si}$ (TMS). The solvent used in all cases was $\mathrm{CDCl}_{3}$ and $\mathrm{CS}_{2}(1: 4 \mathrm{v} / \mathrm{v})$ solution. Low temperature spectra were obtained with the use of a JEOL cooling system.

\section{Results and Discussion}

The title compound was synthesized via direct condensation

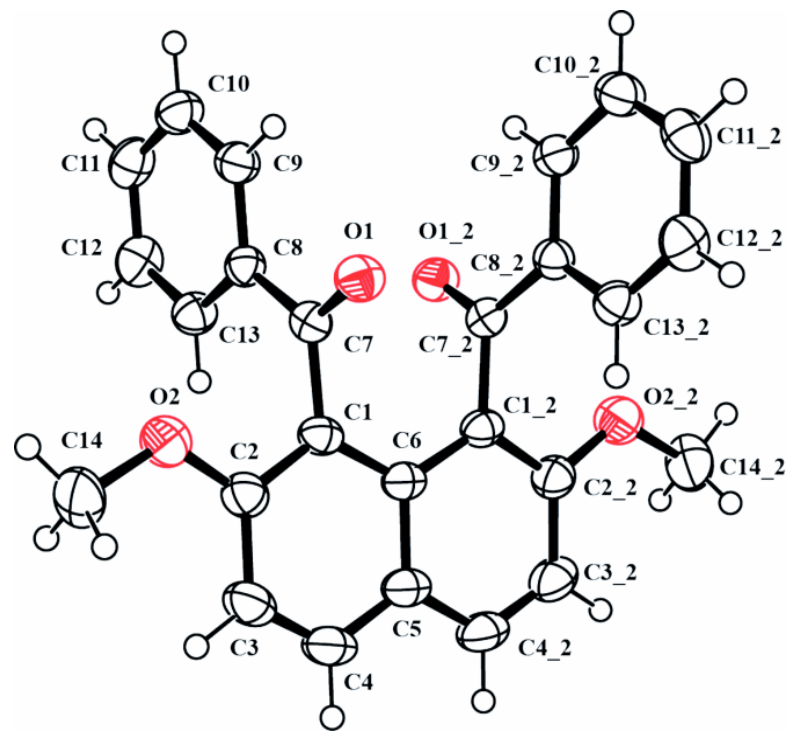

Figure 1. Molecular structure of the title compound, with the atom-labeling scheme and displacement ellipsoids drawn at the $50 \%$ probability level. The symbol "_2" refers to symmetry code: $-x, y,-z+1 / 2$. 
mediated by $\mathrm{P}_{2} \mathrm{O}_{5}-\mathrm{MsOH}$ of 2,7-dimethoxynaphthalene with benzoic acid (see Experimental section). Table 1 shows the crystallographic data of the title compound. Table 2 shows selected bond lengths and angles. Table 3 gives selected torsion angles. Figure 1 gives ORTEP representation of the molecular structure of the title compound, as determined by the structured X-ray analysis [33]. The molecule of the title compound lies across a crystallographic 2-fold axis so that the asymmetric unit contains one half of the molecules. Thus, the two benzoyl groups are situated in an opposite direction (anti-orientation). The benzoyl groups are twisted away from the naphthalene moiety, and the dihedral angle is $80.25(6)^{\circ}$. The torsion angle between the carbonyl group and the naphthalene ring is $-76.73(16)^{\circ}$ [C6-C1-C7-O1] and that between the carbonyl group and the phenyl group is $179.76(13)^{\circ}$ [O1-C7-C8-C13].

Table 1. Crystallographic data and structure refinement parameters.

\begin{tabular}{|c|c|}
\hline Empirical formula & $\mathrm{C}_{26} \mathrm{H}_{20} \mathrm{O}_{4}$ \\
\hline Formula weight & $396.43 \mathrm{~g} \cdot \mathrm{mol}^{-1}$ \\
\hline Crystal shape, colour & Needle, colorless \\
\hline Temperature & $93(2) \mathrm{K}$ \\
\hline Wavelength & $1.54187 \AA$ \\
\hline Crystal sytem & Monoclinic \\
\hline Space group & $\mathrm{C} 2 / \mathrm{c}$ \\
\hline Unit cell dimensions & $\begin{array}{c}\mathrm{a}=13.9677(4) \AA \\
\mathrm{b}=10.2145(3) \AA \\
\mathrm{c}=14.6966(4) \AA \\
\mathrm{b}=109.711(2)^{\circ}\end{array}$ \\
\hline Volume & $1973.95(10) \AA^{3}$ \\
\hline$Z$, calculated density & $4,1.334 \mathrm{Mg} \cdot \mathrm{m}^{-3}$ \\
\hline Absorption coefficient & $0.72 \mathrm{~mm}^{-1}$ \\
\hline $\mathrm{F}(000)$ & 832 \\
\hline Crystal size & $0.50 \times 0.10 \times 0.10 \mathrm{~mm}$ \\
\hline Theta range for data collection & $3.2^{\circ}$ to $68.1^{\circ}$ \\
\hline Limiting indices & $\begin{array}{l}-16 \leq \mathrm{h} \leq 16 \\
-12 \leq \mathrm{k} \leq 12 \\
-17 \leq 1 \leq 17\end{array}$ \\
\hline Reflections collected/unique & $17362 / 1807[$ Rint $=0.027]$ \\
\hline Completeness to theta $=68.21^{\circ}$ & $99.6 \%$ \\
\hline Max. and min transmission & 0.930 and 0.838 \\
\hline Refinement method & Full-matrix least-squares on $\mathrm{F}^{2}$ \\
\hline Data/restraints/parameters & $1807 / 0 / 139$ \\
\hline Goodness-of-fit on $\mathrm{F}^{2}$ & 1.08 \\
\hline Final $R$ indices $[I>2$ sigma $(I)]$ & $\mathrm{R} 1=0.039, \mathrm{wR} 2=0.107$ \\
\hline $\mathrm{R}$ indices (all data) & $\mathrm{R} 1=0.047, \mathrm{wR} 2=0.115$ \\
\hline Largest diff. peak and hole & $0.19 \mathrm{e} \cdot \AA^{-3}$ and $-0.21 \mathrm{e} \cdot \AA^{-3}$ \\
\hline
\end{tabular}

Table 2. Selected bond lengths $(\AA)$ and angles $\left({ }^{\circ}\right)$.

\begin{tabular}{cccc}
\hline $\mathrm{O} 1-\mathrm{C} 7$ & $1.2197(16)$ & $\mathrm{C} 2-\mathrm{C} 1-\mathrm{C} 7$ & $115.70(13)$ \\
$\mathrm{C} 1-\mathrm{C} 2$ & $1.382(2)$ & $\mathrm{C} 6-\mathrm{C} 1-\mathrm{C} 7$ & $123.36(13)$ \\
$\mathrm{C} 1-\mathrm{C} 6$ & $1.4264(17)$ & $\mathrm{O} 1-\mathrm{C} 7-\mathrm{C} 8$ & $121.63(13)$ \\
$\mathrm{C} 1-\mathrm{C} 7$ & $1.5158(19)$ & $\mathrm{O} 1-\mathrm{C} 7-\mathrm{C} 1$ & $118.49(12)$ \\
$\mathrm{C} 7-\mathrm{C} 8$ & $1.4814(19)$ & $\mathrm{C} 8-\mathrm{C} 7-\mathrm{C} 1$ & $119.88(12)$ \\
$\mathrm{C} 8-\mathrm{C} 13$ & $1.3908(19)$ & $\mathrm{C} 13-\mathrm{C} 8-\mathrm{C} 7$ & $122.02(13)$ \\
$\mathrm{C} 8-\mathrm{C} 9$ & $1.396(2)$ & $\mathrm{C} 9-\mathrm{C} 8-\mathrm{C} 7$ & $118.88(13)$ \\
\hline
\end{tabular}

Table 3. Selected torsion angles $\left({ }^{\circ}\right)$.

$\begin{array}{cc}\mathrm{O} 1-\mathrm{C} 7-\mathrm{C} 8-\mathrm{C} 13 & 179.76(13) \\ \mathrm{O} 1-\mathrm{C} 7-\mathrm{C} 8-\mathrm{C} 9 & 0.4(2) \\ \mathrm{C} 2-\mathrm{C} 1-\mathrm{C} 7-\mathrm{O} 1 & 97.99(16) \\ \mathrm{C} 6-\mathrm{C} 1-\mathrm{C} 7-\mathrm{O} 1 & -76.73(16)\end{array}$

In the crystal structure, the molecular packing of the title compound is mainly stabilized by van der Waals interaction. In addition, the packing of the molecule is stabilized by relatively weak $\mathrm{C}-\mathrm{H}$... O hydrogen bonding, namely, C12-H12...O $1^{\mathrm{i}}$ [symmetry code: i) $\mathrm{x},-\mathrm{y}+1, \mathrm{z}$ $+1 / 2$ ], C14-H14B...O1 ${ }^{\mathrm{ii}}$ [symmetry code: ii) $-\mathrm{x}+1 / 2$, y $-1 / 2,-z+1 / 2$ ], and a $\pi-\pi$ stacking interaction [centroidcentroid and interplanar distances of 3.6383 (10) and $3.294 \AA$, respectively]. In the packing, the molecules are arranged by $\mathrm{C}-\mathrm{H}$... O hydrogen bonding along the $c$ axis of the unit cell, and by a $\pi-\pi$ stacking interaction perpendicular the bc plane of the unit cell (Figures 2 and 3). The nonbonding distances are listed in Table 4.

The dynamic behavior of the title compound in solution was estimated by variable temperature NMR (VTNMR) measurement performed in chloroform- $d$ and $\mathrm{CS}_{2}$ $(1: 4, v / v)$ solution from 293 to $173 \mathrm{~K}$. Figure 4(a) shows the ${ }^{1} \mathrm{H}$ VT-NMR spectra of the title compound in the aromatic region. At $293 \mathrm{~K}$, two signals of $\delta 7.21$ and 7.95 ppm are assigned the protons at 3(6)- and 4(5)-positions of the naphthalene ring, respectively. The signals of $\delta$ $7.34,7.49$, and $7.70 \mathrm{ppm}$ are assigned to the protons at $m$-positions, $p$-position, and $o$-positions of benzoyl groups. The signals of $\delta 7.21$ and $7.95 \mathrm{ppm}$ (at $293 \mathrm{~K}$ ) are scarcely changed from 293 to $173 \mathrm{~K}$. On the other hand, the figures of the three signals of $\delta 7.34,7.49$, and $7.70 \mathrm{ppm}$ (at $293 \mathrm{~K}$ ) are drastically changed. The signal of $\delta 7.49 \mathrm{ppm}$ (at $293 \mathrm{~K}$ ) is broadened from 293 to $233 \mathrm{~K}$ then sharpened from 213 to $173 \mathrm{~K}$. The signals of $\delta 7.34$ and $7.70 \mathrm{ppm}$ (at $293 \mathrm{~K}$ ) are broadened from 293 to 213 $\mathrm{K}$ and each of them splits into two broad signals at $193 \mathrm{~K}$. The both of the pairs of broad signals are sharpened again at $173 \mathrm{~K}$. 


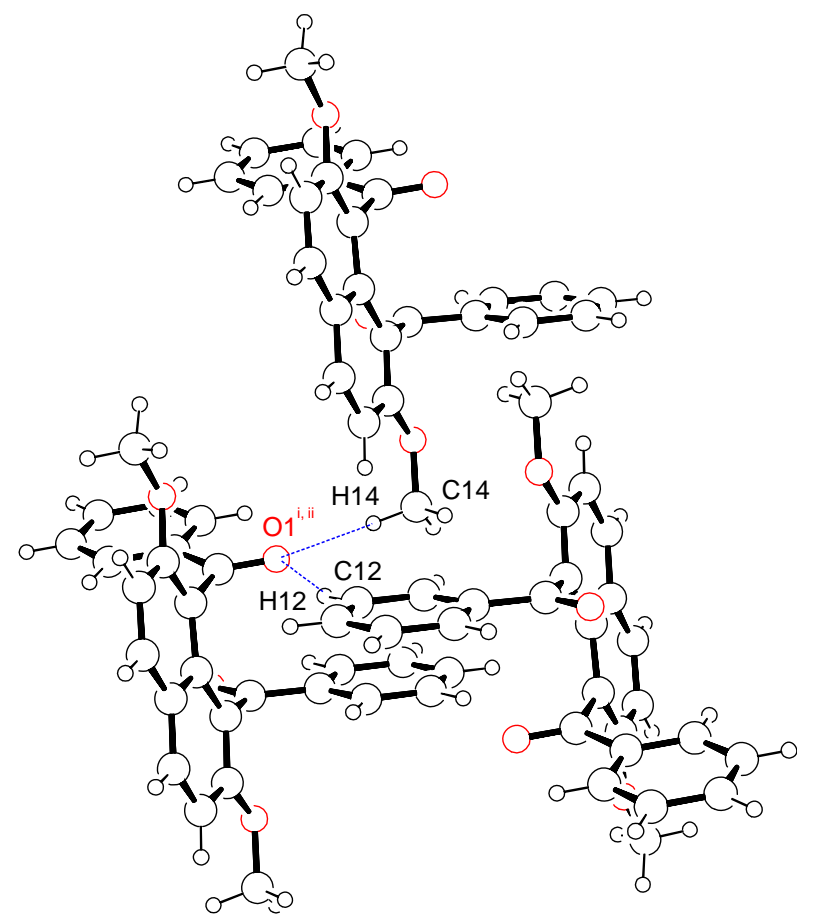

Figure 2. C-H...O interactions of methoxy group and benzene ring with carbonyl group [Symmetry codes: (i) $\mathbf{x},-\mathbf{y}+$ $1, z+1 / 2 ;$ (ii) $-x+1 / 2, y-1 / 2,-z+1 / 2]$.

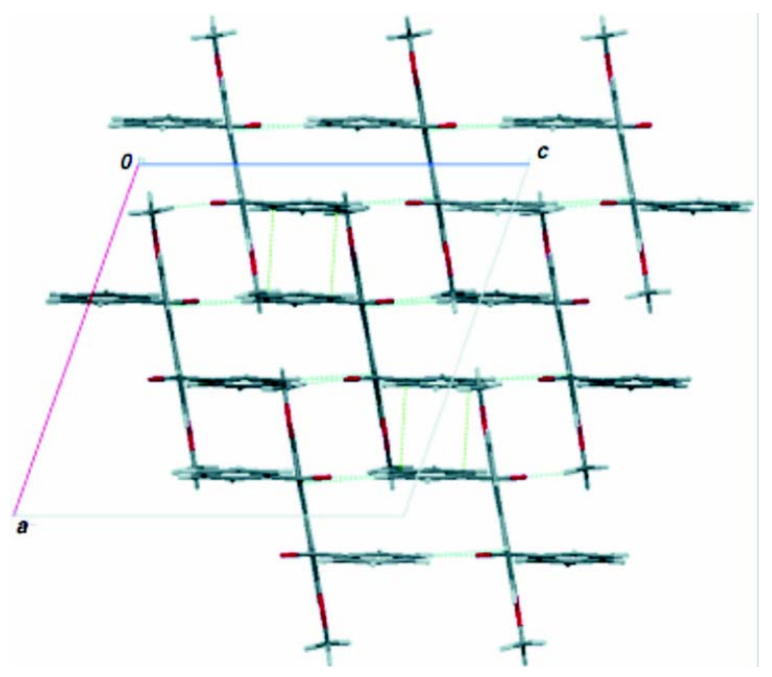

Figure 3. A partial packing diagram of the title compound, viewed down the $b$ axis. The dashed lines indicate hydrogen bonds (blue dashed lines) and $\pi-\pi$ stacking interactions (green lines).

Table 4. Nonbonding distances and related geometrical parameters in 1,8-dibenzoyl-2,7-dimethoxynaphthalene $\left({ }^{\circ}\right)$.

\begin{tabular}{ccccc}
\hline $\mathrm{D}-\mathrm{H} \cdots \mathrm{A}$ & $\begin{array}{c}\mathrm{D}-\mathrm{H} \\
(\AA)\end{array}$ & $\begin{array}{c}\mathrm{H} \cdots \mathrm{A} \\
(\AA)\end{array}$ & $\begin{array}{c}\mathrm{D} \cdots \mathrm{A} \\
(\AA)\end{array}$ & $\begin{array}{c}\mathrm{D}-\mathrm{H} \cdots \mathrm{A} \\
(\text { deg. })\end{array}$ \\
\hline $\mathrm{C} 12-\mathrm{H} 12 \cdots \mathrm{O} 1^{(\mathrm{i})}$ & 0.95 & 2.60 & $3.4987(19)$ & 159 \\
$\mathrm{C} 14-\mathrm{H} 14 \mathrm{~B} \cdots \mathrm{O} 1^{(\mathrm{ii})}$ & 0.98 & 2.39 & $3.344(2)$ & 164 \\
\hline
\end{tabular}

Symmetry codes: (i) $\mathrm{x},-\mathrm{y}+1, \mathrm{z}+1 / 2$; (ii) $-\mathrm{x}+1 / 2, \mathrm{y}-1 / 2,-\mathrm{z}+1 / 2$.

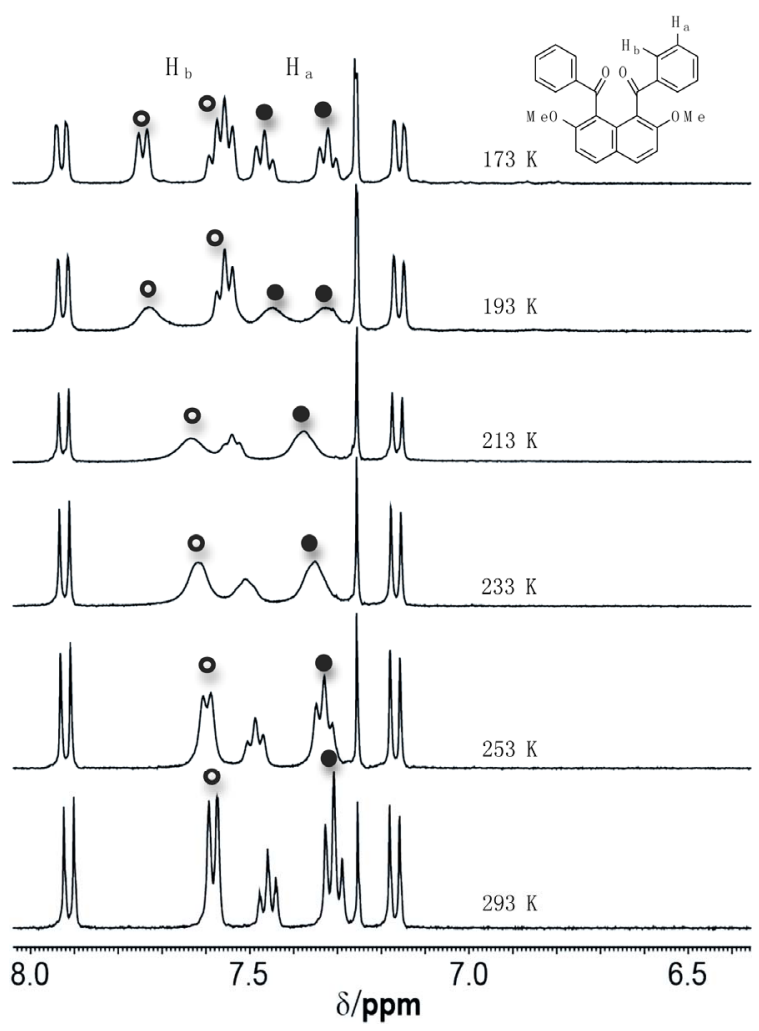

(a)

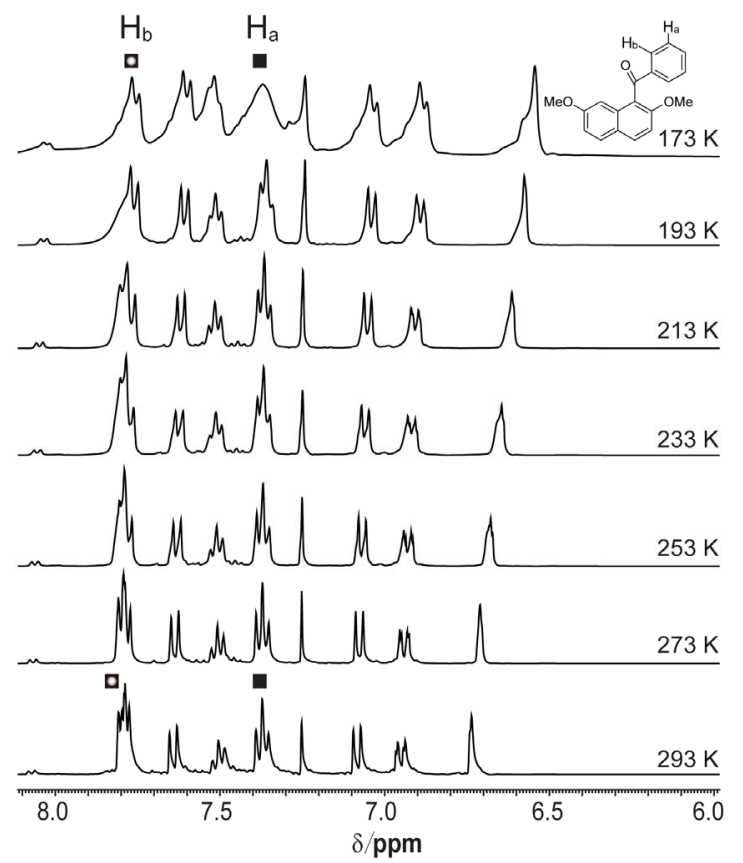

(b)

Figure 4. Variable-temperature ${ }^{1} \mathrm{H}$ NMR study in $\mathrm{CDCl}_{3} /$ $\mathrm{CS}_{2}(1: 4 \mathrm{v} / \mathrm{v})$ : (a) the title compound (6.5 - $\left.8.0 \mathrm{ppm}\right)$; (b) 1-benzoyl-2,7-dimethoxynaphthalene $(6.0-8.0 \mathrm{ppm})$.

The sequent signal changes for the protons at $o$ - and $m$-positions of the benzoyl group as shown in the VTNMR spectra of the title compound suggest that the $\mathrm{C}-\mathrm{C}$ 
bond rotation between benzene ring and ketonic carbonyl group is gradually slowed down with decreasing temperature then the magnetically non-equivalent environment is made on the benzene ring. The rotation barrier of the $\mathrm{C}$ (benzene) $\mathrm{C}$ (carbonyl) bond was calculated as $\Delta \mathrm{G}=$ $9.63 \mathrm{kcal} / \mathrm{mol}$ on the basis of the detailed VT-NMR measurements (Figure 5) [34].

In a similar manner, VT-NMR measurement of the homologous compound of 1-benzoyl-2,7-dimethoxynaphthalene was carried out (Figure 4(b)). For spectrum at $293 \mathrm{~K}$, the signals of $\delta 6.80,7.01,7.17$, and $7.72 \mathrm{ppm}$ are assigned to the protons at 8-, 6-, 5-, and 3-positions of the naphthalene ring, respectively. The two signals of $\delta$ 7.43 and $7.57 \mathrm{ppm}$ are assigned to the protons at $m$-positions and $p$-position of the benzoyl groups. The signals from $\delta 7.84$ to $7.89 \mathrm{ppm}$ are overlapped by the two kinds of signals, the proton at 4-position of the naphthalene ring and the protons at $o$-positions of the benzoyl group. The signals assigned to the protons of the benzoyl group are broadened in the temperature range from 293 to 173 $\mathrm{K}$. However, no split behavior is observed at $173 \mathrm{~K}$.

The title compound and the homologue have two kinds of the $\mathrm{C}-\mathrm{C}$ bonds allowed to rotate, i.e., $\mathrm{C}$ (benzene)$\mathrm{C}$ (carbonyl) and $\mathrm{C}$ (naphthalene)-C(carbonyl) bonds. The steric environment around the neighboring carbonyl groups in the title compound is highly congested as shown in Figure 1. Naturally, the rotation behavior of C(naphthalene)-C(carbonyl) bond should be slower than 1-benzoylnaphthalene homologue. In the consequence, the temperature-dependent $\mathrm{C}$ (benzene)- $\mathrm{C}$ (carbonyl) bond rotation behavior might be observed. In other words, $\mathrm{C}$ (naphthalene)-C(carbonyl) bond in the title compound rotates slowly in the temperature range that the $\mathrm{C}$ (benzene)$\mathrm{C}$ (carbonyl) bond is allowed to rotate freely.

\section{Conclusion}

Conclusively, the crystal structural shapes and the dy-

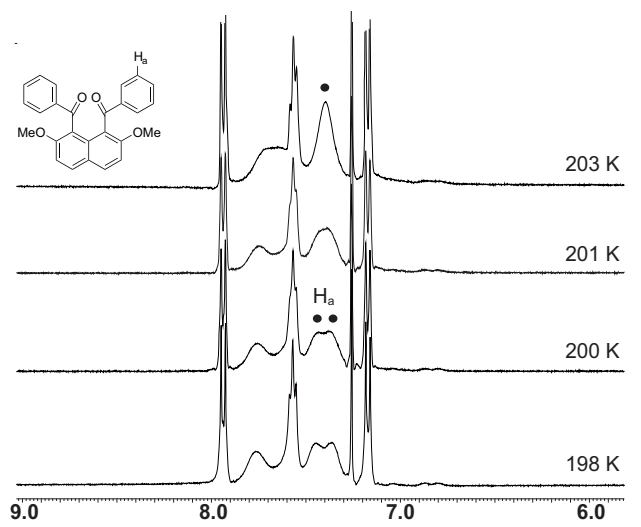

Figure 5. The temperature-dependence of ${ }^{1} \mathrm{H}$ NMR signals of the title compound in $\mathrm{CDCl}_{3} / \mathrm{CS}_{2}(1: 4 \mathrm{v} / \mathrm{v})$ from 203 to 198 K (6.0 - 9.0 ppm). namic feature of solution structure of 1,8-dibenzoyl-2,7dimethoxynaphthalene are clarified. In crystal, the aroyl groups of the compound are perpendicularly attached to the naphthalene ring core and situated in an opposite direction. The two types of $\mathrm{C}-\mathrm{H}$... O interactions of ketonic carbonyl group with benzene ring and methoxy group and $\pi-\pi$ interactions between benzene rings mainly stabilize the molecular packing. According to VT-NMR study, the split signals assigned to the $o$ - and $m$-protons of the benzene ring are observed from 193 to $173 \mathrm{~K}$. Comparison of the dynamic behavior with 1-benzoylnaphthalene homologue shows that the $\mathrm{C}-\mathrm{C}$ bond rotation between ketonic carbonyl group and naphthalene ring in the title compound is enough slow to detect the rotation of the $\mathrm{C}-\mathrm{C}$ bond rotation between benzene ring and ketonic carbonyl group. The structural information of the title compound in solid state and solution affords some hitherto-unknown aspects in molecular formula and intramolecular rotation properties relationship of these non-coplanarly accumulated aromatic rings molecules.

\section{Acknowledgements}

This work was partially supported by the Shorai Foundation for Science and Technology (Tokyo, Japan) and the Ogasawara Foundation for the Promotion of Science and Engineering (Tokyo, Japan).

\section{REFERENCES}

[1] F. Gasparrini, M. Pierini, C. Villani, A. Filippi and M. Speranza, "Induced-Fit in the Gas: Phase Conformational Effects on the Enantioselectivity of Chiral Tetra-Amide Macrocycles," Journal of American Chemical Society, Vol. 130, No. 2, 2008, pp. 522-534. doi:10.1021/ja073287+

[2] N. H. Shah, G. L. Butterfoss, K. Nguyen, B. Yoo, R. Bonneau, D. L. Rabenstein and K. Kirshebaum, "Oligo(Naryl Glycines): A New Twist on Structured Peptoids," Journal of American Chemical Society, Vol. 130, No. 49, 2008, pp. 16622-16632. doi:10.1021/ja804580n

[3] I. Alfonso, M. I. Burguete, F. Galindo, S. V. Luis and L. Vigara, "Molecular Rotors as Simple Models to Study Amide NH-Aromatic Interactions and Their Pole in the Folding of Peptide-Like Structures," Journal of Organic Chemistry, Vol. 72, No. 21, 2007, pp. 7947-7956. doi:10.1021/jo701552b

[4] F. R. Zhang, H. B. Song and G. F. Zi, "Synthesis and Catalytic Activity of Group 5 Metal Amides with Chiral Biaryldiamine-Based Ligands," Dalton Transactions, Vol. 40, No. 7, 2011, pp. 1547-1566. doi:10.1039/c0dt01229g

[5] J.-P. Genet, "Asymmetric Catalytic Hydrogenation. Design of New Ru Catalysts and Chiral Ligands: From Laboratory to Industrial Applications," Accounts of Chemical Research, Vol. 36, No. 12, 2003, pp. 908-918. doi:10.1021/ar020152u

[6] O. Lucchi, "High Symmetry Chiral Auxiliaries Containing Heteroatoms," Pure and Applied Chemistry, Vol. 68, No. 4, 
1996, pp. 945-950.doi:10.1351/pac199668040945

[7] K. Maruoka, "Asymmetric Phase Transfer Catalysis," Wiley-VCH, Weinheim, 2008. doi:10.1002/9783527622627

[8] M. T. Scerba, C. M. Leavitt, M. E. Diener, A. F. DeBlase and $\mathrm{T}$. Lectka, " $\mathrm{NH}^{+}-\mathrm{F}$ Hydrogen Bonding in a Fluorinated "Proton Sponge" Derivative: Integration of Solution, Solid-State, Gas-Phase, and Computational Studies," Journal of Organic Chemistry, Vol. 76, No. 19, 2011, pp. 7975-7984. doi:10.1021/jo2015328

[9] S. Shinamura, E. Miyazaki and K. Takiyama, "Synthesis, Properties, Crystal Structures, and Semiconductor Characteristics of Naphtho[1,2-b:5,6-b']Dithiophene and Diselenophene Derivatives," Journal of Organic Chemistry, Vol. 75, No. 4, 2010, pp. 1228-1234. doi:10.1021/jo902545a

[10] Z. Y. Wang and A. L. Guen, "Synthesis and Properties of Poly(arylene ether)s Containing 1,8-Dibenzoylnaphthalene Units," Macromolecules, Vol. 28, No. 10, 1995, pp. 37283732. doi:10.1021/ma00114a029

[11] Y. L. Jiang, X. N. Gao, G. N. Zhou, A. Patel and A. Javer, "Selective Recognition of Uracil and Its Derivatives Using a DNA Repair Enzyme Structual Mimic," Journal of Organic Chemistry, Vol. 75, No. 2, 2010, pp. 324-333. doi:10.1021/j0901862x

[12] X. F. Mei, R. M. Martin and C. Wolf, "Synthesis of Sterically Crowded Atropisomeric 1,8-Diacridylnaphthalene for Dual-Mode Enantioselective Fluorosensing," Journal of Organic Chemistry, Vol. 71, No. 7, 2006, pp. 2854-2861. doi:10.1021/jo0600353

[13] S. Cohen, M. Thirumalaikumar, S. Pogodin and I. Agranat, "Peri Interactions in Naphthalene Diketones: A Preference for (Z,Z) Conformations," Structure Chemistry, Vol. 15 , No. 4, 2004, pp. 339-346. doi:10.1023/B:STUC.0000026750.39809.07

[14] L.-H. Jing, D.-B. Qin, L. He, S.-J. Gu, H.-X. Zhang and G. Lei, "Dimethyl Naphthalene-1,8-Dicarboxylate," Acta Crystallographica Section E, Vol. 61, No. 11, 2005, pp. 03595-03596. doi:10.1107/S160053680503148X

[15] P. H. Gore and K. Henrick, "1,8-Dibenzoyl-2,7-Dimethylnaphthalene," Acta Crystallographica Section B, Vol. B36, No. 10,1980 , pp. 2462-2465. doi:10.1107/S0567740880009077

[16] A. Okamoto and N. Yonezawa, "Reversible $\mathrm{ArS}_{\mathrm{E}}$ Aroyla tion of Naphthalene Derivatives," Chemistry Letters, Vol. 38, No. 9, 2009, pp. 914-915. doi:10.1246/cl.2009.914

[17] A. Okamoto, R. Mitsui, H. Oike and N. Yonezawa, "Lewis Acid-Mediated $\mathrm{ArS}_{\mathrm{E}}$ Aroylation of Naphthalene Derivative: Distinct Second Aroylation Behavior of Naphthyl Ketone," Chemistry Letters, Vol. 40, No. 11, 2011, pp. 1283-1284. doi:10.1246/cl.2011.1283

[18] K. Nakaema, A. Okamoto, K. Noguchi and N. Yonezawa, "1,8-Bis(4-Chlorobenzoyl)-2,7-Dimethoxynaphthalene," Acta Crystallographica Section E, Vol. E63, No. 10, 2007, p. 04120. doi:10.1107/S1600536807045114

[19] A. Okamoto, R. Mitsui, S. Watanabe, T. Tsubouchi and N. Yonezawa, "Chemospecific and Regioselective Etheral Methyl-Oxygen Bond Cleavage Behavior of Aroylated
Dimethoxynaphthalenes by Combined Action of $\mathrm{AlCl}_{3}$ and Aroyl Group," International Journal of Organic Chemistry, Vol. 2, No. 3, 2012, pp. 194-201. doi:10.4236/ijoc.2012.23029

[20] T. Tsumuki, A. Isogai, A. Nagasawa, A. Okamoto and N. Yonezawa, "2,7-Dimethoxy-1-(2-Naphthoyl) Naphthalene," Acta Crystallographica Section E, Vol. E68, No. 8, 2012, p. o2595. doi:10.1107/S1600536812033545

[21] R. Sakamoto, K. Sasagawa, D. Hijikata, A. Okamoto and N. Yonezawa, "1,8-Dibenzoylnaphthalene-2,7-Diyl Dibenzate," Acta Crystallographica Section E, Vol. E68, No. 8, 2012, p. o2454. doi:10.1107/S1600536812030991

[22] K. Sasagawa, D. Hijikata, R. Sakamoto, A. Okamoto and N. Yonezawa, "[2,7-Dimethoxy-8-(4-Propylbenzoyl)Naphthalen-1-yl](4-Propylphenyl)Methanone," Acta Crystallographica Section E, Vol. E68, No. 8, 2012, p. o2596. doi:10.1107/S1600536812033582

[23] K. Sasagawa, D. Hijikata, T. Kusakabe, A. Okamoto and N. Yonezawa, "4- $\{[8-(4-$ Acetyloxybenzoyl)-2,7-Dimethoxynaphthalen-1-yl]Carbonyl Phenyl Acetate," Acta Crystallographica Section E, Vol. E68, No. 8, 2012, p. o2503. doi:10.1107/S160053681203228X

[24] T. Muto, K. Sasagawa, A. Okamoto, H. Oike and N. Yonezawa, "[8-(4-Chlorobenzoyl)-2,7-Dimethoxy-Naphthalen-1-yl](2,4,6-Trimethylphenyl)Methanone," Acta Crystallographica Section E, Vol. E68, No. 3, 2012, p. 0906. doi:10.1107/S1600536812008112

[25] T. Muto, K. Sasagawa, A. Okamoto, H. Oike and N. Yonezawa, “(3,5-Dimethylphenyl)[8-(3,5-Dimethylbenzoyl)-2, 7-Dimethoxynaphthalen-1-yl] Methanone," Acta Crystallographica Section E, Vol. E68, No. 4, 2012, p. o1200. doi:10.1107/S1600536812012202

[26] T. Tsumuki, S. Murohashi, A. Nagasawa, A. Okamoto and N. Yonezawa, "(3,6-Dimethoxynaphthalen-2-yl) (Naphthalen2-yl)Mathanone," Acta Crystallographica Section E, Vol. E68, No. 9, 2012, p. o2653. doi:10.1107/S1600536812034186

[27] P. Eaton, G. R. Carlson and J. T Lee, "Phosphorus Pentoxide-Methane Sulfonic Acid. Convenient Alternative to Polyphosphoric Acid," Journal of Organic Chemistry, Vol. 38, No. 23, 1973, pp. 4071-4073. doi:10.1021/jo00987a028

[28] A. M. Gorelik, A. V. Reznichenko, N. A. Andronova, E. A. Luk'yanets, "Acylation of 2,7-Dimethoxynaphthalene," Zhurnal Organicheskoi Khimii, Vol. 19, No. 1, 1983, pp. 199. 206.

[29] Rigaku, "PROCESS-AUTO,” Rigaku Corporation, Tokyo, 1998.

[30] Rigaku/MSC, “CrystalStructure,” Rigaku/MSC, The Woodlands, Houston, 2004.

[31] M. C. Burla, R. Caliandro, M. Camalli, B. Carrozzini, G. L. Cascarano, L. De Caro, C. Giacovazzo, G. Polidori and R. Spagna, "SIR2004: An Improved Tool for Crystal Structure Determination and Refinement," Journal of Applied Crystallography, Vol. 38, No. 2, 2005, pp. 381-388. doi:10.1107/S002188980403225X

[32] G. M. Sheldrick, "A Short History of SHELX," Acta Crystallographica Section A, Vol. A64, No. 1, 2008, pp. 112-122. doi:10.1107/S0108767307043930 
[33] K. Nakaema, S. Watanabe, A. Okamoto, K. Noguchi and N. Yonezawa, "1,8-Dibenzoyl-2,7-Dimethoxy-Naphthalene," Acta Crystallographica Section E, Vol. E64, No. 5, 2008, p. 0807. doi:10.1107/S1600536808007009

[34] H. S. Gutowsky and C. H. Holm, "Rate Processes and
Nuclear Magnetic Resonance Spectra II. Hindered Internal Rotation of Amides," Journal of Chemical Physics, Vol. 25, 1956, pp. 1228-1234. 